\title{
ARUS UTAMA PERDEBATAN HUKUM PERKAWINAN BEDA AGAMA
}

\author{
Khamami Zada \\ Fakultas Syariah dan Hukum UIN Syarif Hidayatullah Jakarta \\ Jl. Ir. H. Juanda 95, Ciputat, Jakarta \\ E-mail: khamamizada@gmail.com
}

\begin{abstract}
Mapping the Mainstreaming Debate Regarding to Interfaith Marriage Law. This article intends to observe the linkage of the implementation of interfaith marriage law with the opinion of Islamic jurists' and to political and social change in a country. Interfaith marriage law-as occurred in (former) North Yemen, Jordan, Algeria, and Iraq-is not influenced by the Islamic school of thought of the majority population. In contrary, interfaith marriage in the aforementioned states is not inline with the mainstream opinion of islamic jurists that forbidding softly (makrüh) Muslim man to marry a woman of Abl al-Kitäb. The regulation is obviously influenced by the rise of Islamism, such as the Muslim brotherhood in Jordan, Front Islamic Salvation in Algeria, and the growing influence of Shiite movements in Iraq and North Yemen in establishing religious conservatism in matters of interfaith marriage. Thus, it can be understood why those countries prefer to refer text of the Quran that regulate interfaith marriage law.
\end{abstract}

Keywords: interfaith marriage law, islamic family law, Abl al-Kitäb

\begin{abstract}
Abstrak: Arus Utama Perdebatan Hukum Perkawinan Beda Agama. Artikel ini ingin menguji keterhubungan pemberlakuan hukum perkawinan beda agama dengan pendapat-pendapat ulama fikih dan perubahan sosial politik suatu negara. Hukum perkawinan beda agama di Yaman Utara, Yordania, Aljazair, dan Irak tidak begitu sepenuhnya dipengaruhi oleh mazhab fikih yang dianut mayoritas penduduknya. Justru perkawinan beda agama di negara-negara tersebut sedikit keluar dari mainstream pendapat ulama fikih yang memakruhkan laki-laki Muslim yang menikah dengan wanita Ablal-Kitäb. Posisi ini diambil bukan karena dipengaruhi oleh kolonialisme Barat yang berlangsung lama dalam memberlakukan hukum, melainkan kuatnya Islamisme, seperti Ikhwanul Muslimin di Yordania, Front Islamic Salvation di Aljazair, dan kuatnya pengaruh gerakan Syiah di Irak dan Yaman Utara dalam membangun konservatisme agama dalam urusan perkawinan beda agama. Tidak heran jika empat negara ini mengambil jalan kembali ke teks Alquran untuk mengatur hukum perkawinan beda agama.
\end{abstract}

Kata Kunci: hukum perkawinan beda agama, hukum keluarga Islam, Abl al-Kitāb

\section{Pendahuluan}

Salah satu isu penting dalam materi pembaharuan hukum keluarga di negara-negara Muslim adalah perkawinan beda agama. Meskipun materi ini tidak banyak dibahas dalam Undang-undang Hukum Keluarga di negera-negara Muslim, tetapi tingkat signifikansinya begitu jelas jika dikaitkan dengan tingkat kemajemukan agama yang dianut warga negara di setiap negara-negara Muslim dan tingkat perubahanperubahan sosial dan politiknya.

Di masa modern ini, negara-negara Muslim mulai mengatur status hukum perkawinan beda agama, terutama perkawinan $A b l$ al-Kitäb dan yang bukan Abl al-Kitäb. Irak, Yaman Utara, Aljazair, dan Yordania

Naskah diterima: 5 Juli 2012, direvisi: 19 Oktober 2012, disetujui untuk terbit: 30 Oktober 2012 merupakan negara-negara yang mengatur perkawinan beda agama di dalam Undang-undang Hukum Keluarganya. Irak yang penduduknya didominasi pengikut mazhab Hanafĩ memiliki Qānūn al-Ahwāl alShakbsiyyah Nomor 188 tahun 1959 yang diperbarui hingga UU Nomor 11 tahun 1980. Aljazair yang mayoritas penduduknya pengikut mazhab Mālikī dan sebagian Syiah Ibadi memiliki Marriage Ordinance Nomor 274 Tahun 1959 yang diperbarui dengan Algerian Family Code Nomor 11 Tahun 1984. Yordania yang menganut mazhab Hanafī memiliki Qānūn alAbwäl al-Shakhsiyyah Nomor 61 Tahun 1976. Yaman Utara yang mayoritas penduduknya pengikut Syiah Zaidiyah memiliki Qānūn al-Usrah Nomor 3 Tahun 1978. Empat Negara ini masuk dalam kategori Negara Muslim yang telah melakukan pembaharuan Hukum Keluarga Islam secara berkesinambungan atau 
bertahap.

Pengaturan perkawinan beda agama yang diatur dalam Undang-undang Hukum Keluarga Irak, Yaman Utara, Aljazair, dan Yordania sesungguhnya merupakan upaya negara dalam memberikan kejelasan status hukum di tengah perdebatan di kalangan Muslim (fukaha dan mufasir) sejak zaman klasik hingga sekarang tentang hukum perkawinan beda agama.

\section{Perkawinan Beda Agama dalam Fikih}

Perkawinan beda agama sesungguhnya telah diatur dalam Alquran, baik kepada laki-laki Muslim maupun perempuan Muslimah. Berdasarkan ayat-ayat Alquran, para ulama membagi hukum perkawinan beda agama ke dalam beberapa kategori.

Pertama, hukum menikahi musyrik dan murtad. Para ulama bersepakat bahwa seorang Muslim diharamkan menikahi musyrik. Orang-orang yang telah menyekutukan Allah Swt. diharamkan untuk dinikahi oleh Muslim, termasuk di dalamnya murtad. Mazhab Hanafiyyah, Shāfi'iyyah, dan mazhab lainnya menyamakan murtad dengan musyrik, sehingga menikahi murtad pun hukumnya adalah haram. ${ }^{1}$ Karena orang yang murtad adalah orang yang tidak lagi memegangi agama Allah Swt.

Dalil yang dijadikan argumen adalah:

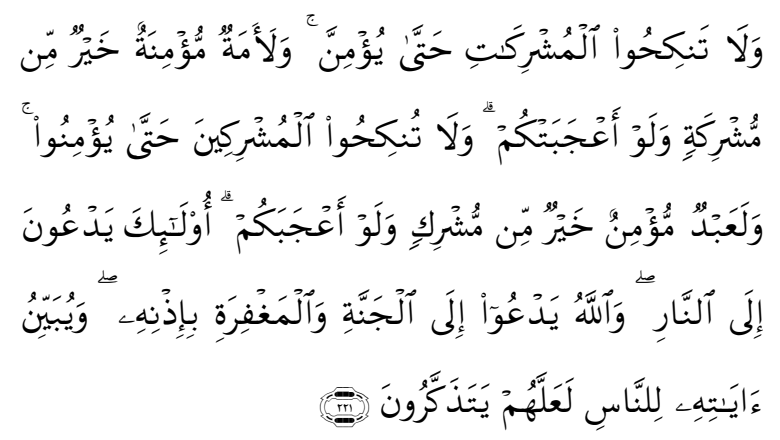

Dan janganlah kamu menikahi wanita-wanita musyrik, sebelum mereka beriman. Sesungguhnya wanita budak yang mukmin lebih baik dari wanita musyrik, walaupun dia menarik hatimu. dan janganlah kamu menikahkan orang-orang musyrik (dengan wanita-wanita mukmin) sebelum mereka beriman. Sesungguhnya budak yang mukmin lebih baik dari orang musyrik, walaupun dia menarik hatimu. Mereka mengajak ke neraka, sedang Allah mengajak ke surga dan ampunan dengan izin-Nya. Dan Allah menerangkan ayat-ayat-Nya (perintah-perintah-Nya) kepada manusia supaya mereka mengambil pelajaran. (Q.s. Al-Baqarah [2]: 221).

Larangan menikahi juga ditujukan kepada ateis. 'Abd al-'Azīz Muhammad 'Azzām dan 'Abd al-Wahhāb Sayyed Hawwās berpendapat tidak boleh menikahi

${ }^{1}$ Wahbah al-Zuhaylī, al-Fiqh al-Islāmī wa Adillatuh, jilid IX, (Bayrūt: Dār al-Fikr, 1997), h. 665. wanita ateis yang ingkar terhadap semua agama dan tidak beriman kepada Tuhan. Demikian juga tidak boleh menikahi wanita yang beriman kepada agama selain agama samawi, seperti agama-agama yang diciptakan manusia seperti agama Majusi yang menyembah api, Wathaniyah yang menyembah berhala, Sabiah yang menyembah bintang-bintang dan benda-benda di langit dan Hindu yang menyembah sapi. Demikian juga lakilaki muslim dilarang menikahi wanita yang dilahirkan dari campuran antara $A b l$ al-Kitäb dengan Majusi, sekalipun bapaknya Ahl al-Kitäb karena memenangkan keharaman. $^{2}$

Kedua, menikahi orang kafir. Berdasarkan pendapat ijmak ulama, seorang perempuan Muslimah diharamkan menikah dengan laki-laki kafir. ${ }^{3}$ Dalil yang digunakan adalah surah al-Baqarah [2] ayat 221. Begitu juga seorang perempuan Muslimah tidak boleh dinikahi laki-laki $A b l$ al-Kitāb, termasuk Majusi. Pendapat ini memperlihatkan bahwa perempuan Muslimah hanya boleh dinikahi laki-laki Muslim, tidak boleh dinikahi oleh musyrik, murtad, dan kafir (Ahl al-Kitāb).

Ketiga, ulama bersepakat bahwa laki-laki Muslim boleh menikahi wanita $A b l$ al-Kitäb. ${ }^{4}$ Dalilnya adalah firman Allah Swt:

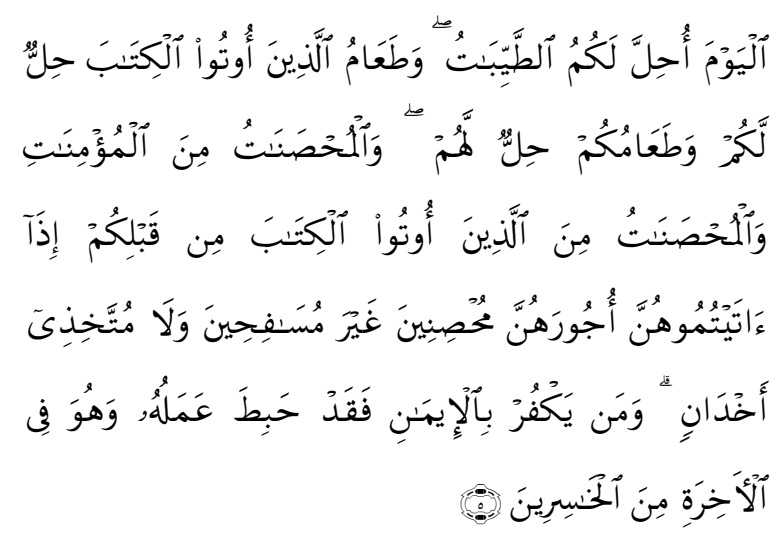

Pada hari ini dihalalkan bagimu yang baik-baik, makanan (sembelihan) orang-orang yang diberi al-Kitāb itu halal bagimu, dan makanan kamu halal (pula) bagi mereka. (Dan dihalalkan mangawini) wanita yang menjaga kehormatan diantara wanita-wanita yang beriman dan wanita-wanita yang menjaga kehormatan di antara orang-orang yang diberi al-Kitāb sebelum kamu, bila kamu telah membayar mas kawin mereka dengan maksud menikahinya, tidak dengan maksud berzina dan tidak (pula) menjadikannya gundik-gundik. Barangsiapa yang

${ }^{2}$ Lihat, 'Abd al-'Azīz Muhammad 'Azzām dan 'Abd al-Wahhāb Sayyed Hawwās, al-Usrah wa Ahkāmuhā fì al-Tashrī' al-Islāmì, terjemahan Fiqh Munakahat, (Jakarta: Sinar Grafika Offset, 2009), h. 169. 6653.

${ }^{3}$ Wahbah al-Zuhaylī, al-Fiqh al-Islämī wa Adillatuh, jilid IX, h.

${ }^{4}$ Wahbah al-Zuhaylī, al-Fiqh al-Islāmī wa Adillatuh, jilid IX, h. 6653. Lihat Rusli Hasbi, Rekonstruksi Hukum Islam: Kajian Kritis Sahabat Terhadap Ketetapan Rasulullah Saw, (Jakarta: Al-Irfan Publishing, 2007), h. 154-155. 
kafir sesudah beriman (tidak menerima hukum-hukum Islam), maka hapuslah amalannya dan ia di hari kiamat termasuk orang-orang merugi.(Q.s. Al-Mā'idah [5]: 5).

Pendapat serupa dikemukakan Ibn Qudāmah, ia berkata, "Tidak ada perbedaan di kalangan ulama mengenai kebolehan menikahi wanita-wanita $A b l$ al-Kitāb". ${ }^{5}$ Al-Jaș̣āṣ juga berpendapat, "Kami tidak menemukan seorang pun dari Sahabat dan Täbiīn yang mengharamkan menikahi Abl al-Kitäb" ${ }^{6}$

Hal ini didukung oleh praktik para sahabat yang menikahi Ahl al-Kitāb. Di dalam sejarahnya, para Sahabat banyak yang menikahi wanita non-Muslim. Hudhayfah ibn Yaman pernah menikahi wanita Yahudi dan Nasrani. Talhah ibn 'Ubaydillah menikahi wanita Yahudi penduduk Syam, 'Uthmān ibn 'Affān menikahi Naylah bint al-Qarafisah al-Kalabiyah, seorang Nasrani' serta Jābir ibn 'Abd Allāh pernah menikahi Abl al-Kitāb. Dari penjelasan di atas di antara para Sahabat banyak yang menikahi Abl al-Kitäb. Namun demikian, 'Umar ibn al-Khațāâ dan Ibn 'Umar berpendapat bahwa menikahi wanita Ahl al-Kitāb dilarang. 'Umar ibn al-Khațāāb memandang jika pintu kebolehan menikahi wanita Ahl al-Kitäb dibuka dengan leluasa dikhawatirkan akan mendatangkan pengaruh negatif yang tidak diinginkan. Muslim laki-laki akan berbondong-bondong meninggalkan para Muslimah dan tidak menikahi mereka dan tentunya hal tersebut dapat mendatangkan pelbagai macam bahaya bagi eksistensi Dawlah Islämiyyah, seperti terbongkarnya rahasia negara karena informasi mereka. Mereka juga dikhawatirkan akan merusak generasi Muslimah melalui doktrin agama, akhlak, dan lain sebagainya. Sebagai kepala negara, 'Umar berpendapat bahwa masalah apa saja beserta wasilah dan sarananya yang dapat menimbulkan bahaya harus ditutup. Dengan alasan ini, 'Umar melarang para Sahabat untuk menikahi Abl alKitāb. Ia menulis surat kepada Khudhayfah ibn Yaman saat menjadi gubernur agar menceraikan istrinya yang Ahl al-Kitā $b .{ }^{8}$

'Umar ibn al-Khațāa tidak mengatakan bahwa menikahi wanita Abl al-Kitāb hukumnya haram. Karena Alquran sendiri tidak mengharamkannya. Ia melarang para Sahabat untuk menikahi Abl alKitāb bukan karena haram, tetapi semata-mata untuk mencegah ditinggalkannya para wanita Muslimah akibat ketertarikan para Sahabat kepada wanita-wanita Abl al-Kitäb. Jika saja perkawinan itu diperbolehkan,

\footnotetext{
${ }^{5}$ Ibn Qudāmah, Al-Sharh al-Kabìr 'alā Matn al-Mughnī, Jilid VII, (Suriah: Dār al-Bayān, t.th), h. 500.

${ }^{6}$ Abū Bakr al-Jassās, Aḥkām al-Qur'ān, Jilid I, h. 393.

${ }^{7}$ Wahbah al-Zuhaylī, al-Fiqh al-Islämì wa Adillatuh, jilid IX, h. 6653.

${ }^{8}$ Lihat Rusli Hasbi, Rekonstruksi Hukum Islam, h. 154-155.
}

maka mereka akan berlomba-lomba menikahi wanita Abl al-Kitäb karena kecantikan dan tipu daya mereka dan wanita-wanita Muslimah akan terlantar. ${ }^{9}$

Larangan yang berlaku bagi Khudhayfah ibn Yaman lebih didasari oleh alasan bahwa ia adalah salah seorang gubernur dan sebagai teladan bagi Muslim lainnya. Sekiranya 'Umar tidak memerintahkan kepadanya untuk menceraikan isterinya yang berasal dari $\mathrm{Abl}$ alKitāb, niscaya umat akan mengikuti jejaknya sehingga menikahi mereka akan dicontoh oleh masyarakat Muslim sepanjang masa. ${ }^{10}$

Adapun menurut mazhab Hanafī, Shāfīì, dan Mālikī, menikahi Ahl al-Kitāb hukumnya adalah makruh. Mazhab Hanbalī menyatakan menikahi $A h l$ al-Kitāb adalah khilāf yang utama karena 'Umar ibn alKhaț̣āb pernah mengatakan kepada para sahabat yang menikahi wanita Ahlal-Kitäb yang berstatus dhimmìagar menceraikannya. Para sahabat pun menceraikan istriistri dari Ahl al-Kitāb, kecuali Khudhayfah. Adapun $A b l$ al-Kitāb yang berstatus harbī, menurut mazhab Hanafī haram hukumnya menikahi mereka apabila berada di dār al-ḥarb. Mazhab Shāfî̀ dan Mālikī berpendapat haram hukumnya. ${ }^{11}$

'Abd al-Raḥmān al-Jāzirī mengemukakan bahwa Mazhab Hanafi mengharamkan menikahi Abl alKitāb yang berada di dār al-ḥarb. Mazhab Mālikī memakruhkan Ahl al-Kitāb secara mutlak, baik dhimmi maupun harbī. Tapi, menikahi Abl al-Kitāb di dār al-harb sangat dimakruhkan. Pendapat kedua dari mazhab Mālikī justru tidak memakruhkan secara mutlak. Sedangkan mazhab Shāfi'̄ menikahi Ahl alKitāb makruh hukumnya apabila mereka berada di dēr al-Isläm dan lebih makruh lagi jika mereka berada di dār al-ḩarb. ${ }^{12}$

Adapun menurut Muhammad Jawad Mughniyah, keempat mazhab sepakat bahwa sibh kitāb, seperti Majusi, tidak boleh dinikahi. Keempat mazhab hanya sepakat bahwa seorang laki-laki Muslim boleh menikahi wanita Abl al-Kitāb, yakni wanita Yahudi dan Nasrani dan tidak sebaliknya. ${ }^{13}$

Sedangkan Mazhab Imāmiyyah berpendapat bahwa wanita Muslimah tidak boleh menikah dengan laki-laki Abl al-Kitäb, tetapi mereka berbeda pendapat tentang kebolehan laki-laki Muslim menikahi wanita $\mathrm{Abl}$ al-

${ }^{9}$ Lihat Rusli Hasbi, Rekonstruksi Hukum Islam, h. 155-56

${ }^{10}$ Lihat Rusli Hasbi, Rekonstruksi Hukum Islam, h. 156

${ }^{11}$ Wahbah al-Zuhaylī, al-Figh al-Islāmī wa Adillatuh, jilid IX, h. 6654.

12 'Abd al-Rahmān al-Jazīīi, Kitāb al-Fiqh 'alā Madhāhib al-Arba'ah, jilid IV, (Bayrūt: Dār al-Fikr al-'Ilmiyah, t.t.), h. 73.

${ }^{13}$ Muhammad Jawad Mughniyah, Figh Lima Mazhab, cet. IV, (Jakarta: PT. Lentera Basritama, 1999), h. 336. 
Kitāb. Sebagian dari mereka berpendapat bahwa hal itu tidak baik dalam bentuk nikah däim atau mut'a ${ }^{14}$. Mereka berpegang pada ayat berikut ini:

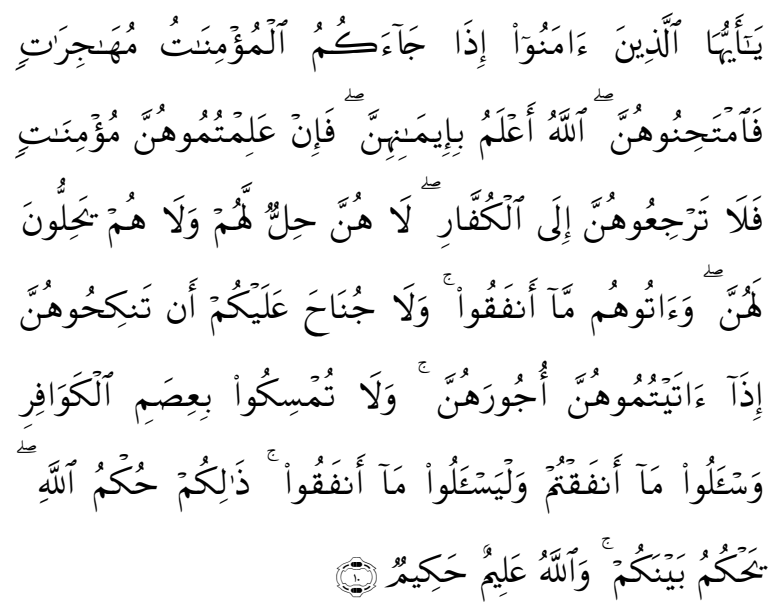

Hai orang-orang yang beriman, apabila datang berhijrah kepadamu perempuan-perempuan yang beriman, maka hendaklah kamu uji (keimanan) mereka. Allah lebih mengetahui tentang keimanan mereka, maka jika kamu telah mengetahui bahwa mereka (benar-benar) beriman, maka janganlah kamu kembalikan mereka kepada (suami-suami mereka) orang-orang kafir. Mereka tiada halal bagi orang-orang kafir itu dan orang-orang kafir itu tiada halal pula bagi mereka. Dan berikanlah kepada (suami suami) mereka, mahar yang telah mereka bayar. Dan tiada dosa atasmu mengawini mereka apabila kamu bayar kepada mereka maharnya. Dan janganlah kamu tetap berpegang pada tali (perkawinan) dengan perempuan-perempuan kafir; dan hendaklah kamu minta mahar yang telah kamu bayar; dan hendaklah mereka meminta mahar yang telah mereka bayar. Demikianlah hukum Allah yang ditetapkan-Nya di antara kamu. Dan Allah Maha Mengetahui lagi Maha Bijaksana. (Q.s. alMumtahanah [60]: 10)

Sedangkan kelompok Imāmiyyah lainnya mengatakan bahwa menikahi wanita-wanita Ahlal-Kitāb itu boleh dalam bentuk nikah sementara, tetapi bukan dalam bentuk nikah däim. Mereka mengompromikan antara dalil yang melarang dan yang membolehkan. Dalil yang menunjukkan larangan, menurut mereka adalah larangan untuk nikah däim, sedangkan dalil yang membolehkan adalah nikah sementara. ${ }^{15}$

Namun demikian, terjadi perbedaan pendapat dalam menafsirkan Abl al-Kitäb. Mayoritas ulama mengatakan bahwa Ahl al-Kitäb adalah Yahudi dan Nasrani. Pendapat ini diperkuat oleh Alquran, surah al-An'ām [6] ayat 156, "Kami turunkan Alquran itu agar kamu (tidak) mengatakan bahwa Kitab itu hanya diturunkan kepada dua golongan saja sebelum kamu”. Sebagian ulama berpendapat bahwa Ahl al-Kitāb juga mencakup orang-orang yang berpegang teguh kepada SubufIbrähìm, Shis, dan Zabürkarena mereka berpegang

\footnotetext{
${ }^{14}$ Muhammad Jawad Mughniyah, Fiqh Lima Mazhab, h. 336.

${ }^{15}$ Muhammad Jawad Mughniyah, Fiqh Lima Mazhab, h. 337.
}

teguh kepada Kitab Allah seperti halnya orang-orang Yahudi dan Nasrani. Adapun Șäbìün menurut Imam Aḥmad dan Imam Shāfi'i adalah segolongan dengan Nasrani. Sedangkan menurut Abū Thawr dan Ibn Hazm al-Zāhirī, Majusi juga termasuk dalam kategori Abl al-Kitā̄b ${ }^{16}$ karena Rasulullah pernah bersabda, "Perlakukanlah mereka (orang-orang Majusi) seperti $A b l$ al-Kitāb". Namun menurut kebanyakan fukaha, Majusi itu bukan Ahl al-Kitāb. Sedangkan Samirah (kelompok agama Yahudi) dan Șābiah (kelompok agama Nasrani) menurut Abū Hanīfah dan mazhab Hanbalī mereka termasuk Ahl al-Kitāb. ${ }^{17}$

Ulama juga berbeda pendapat dalam memahami maksud al-mubșanāt min abl al-kitāb. Imam Shāfi'ī berpendapat al-muḅsanāt adalah wanita merdeka, sehingga Imam Shāfi’i berpendapat tidakboleh menikahi Abl al-Kitāb. Bagi Imam Shāf'ī, larangan mengawini wanita Ahl al-Kitāb disebabkan dua kekurangan, yaitu kafir dan budak. Abū Hanīfah mengatakan al-muḅsanāt adalah wanita-wanita yang memelihara kehormatan diri mereka (tidak berbuat zina). Maka, dalam pandangan Abū Hanīfah, wanita Abl al-Kitāb boleh dinikahi. ${ }^{18}$

Ulama juga berbeda pendapat mengenai dhimmi dan harbī. Sa īd Musayyab mengatakan bahwa Alquran membolehkan mengawini wanita Ahl al-Kitāb, baik dhimmi dan harbì. Pendapat ini berbeda dengan mayoritas ulama yang melarang menikahi wanita $A b l$ al-Kitāb yang harbì dan memperbolehkan menikahi wanita yang dhimmi. ${ }^{19}$ Larangan menikahi wanita Abl al-Kitāb yang harbī jelas-jelas mengandung spirit bahwa Ahl al-Kitāb yang harbì akan membahayakan umat Islam.

\section{Perkawinan Beda Agama dalam Hukum Positif Negara-negara Muslim}

Ada sejumlah negara yang mengatur hukum perkawinan beda agama, seperti Yaman Utara, Yordania, Irak, dan Aljazair. Di Yaman Utara, misalnya, perkawinan beda agama diatur dalam Undang-undang Hukum Keluarga (Qànūn al-Usrah) No. 31978/. Pasal 47 menyebutkan:

Ketika seorang suami non-Muslim masuk Islam dan isterinya yang bukan $A b l$ al-Kitāb tidak masuk Islam atau agama $A h l$ al-Kitāb, maka perkawinan tersebut dapat dibatalkan. Ketika seorang isteri non-Muslim masuk Islam sementara suaminya tetap non-Muslim, perkawinan dapat dibatalkan. Ketika salah seorang suamiistri keluar dari Islam, maka perkawinan dibatalkan.

${ }^{16}$ Rusli Hasbi, Rekonstruksi Hukum Islam, h. 149-50.

${ }^{17}$ Wahbah al-Zuhaylī, al-Figh al-Islāmī wa Adillatuh, jilid IX, h. 6655-6.

${ }^{18}$ Rusli Hasbi, Rekonstruksi Hukum Islam, h. 154-55.

${ }^{19}$ Rusli Hasbi, Rekonstruksi Hukum Islam, h. 154-55. 
Pengaturan perkawinan beda agama di Yaman Utara masih memandang bahwa seorang perempuan tidak boleh menikah dengan non-Muslim dan seorang laki-laki hanya boleh menikah dengan wanita Ahl alKitāb. Sehingga dalam Hukum Keluarga Yaman Utara ditetapkan bahwa perkawinan dapat dibatalkan ketika suami (yang non-Muslim) masuk Islam, sedangkan isterinya (yang bukan Abl al-Kitäb) tidak masuk Islam atau tidak beragama Ahlal-Kitāb. Begitu pula sebaliknya ketika sang suami tetap non-Muslim, sementara istrinya masuk Islam, perkawinan dibatalkan. Hal ini berarti hukum perkawinan beda agama mengikuti pendapat fikih bahwa perkawinan harus didasarkan pada prinsip, "suami harus beragama Islam atau istri beragama $A b l$ al-Kitāb".

Yaman Utara adalah negara yang mayoritas penduduknya pengikut Syiah. ${ }^{20}$ Tidak mengherankan jika pengaturan perkawinan beda agama di Yaman Utara sejalan dengan pendapat ulama Syiah tentang kebolehan laki-laki Muslim menikahi wanita $A b l$ alKitāb. Sebagian dari mereka hanya berpendapat bahwa laki-laki Muslim yang menikahi wanita Abl al-Kitāb tidak baik dalam bentuk nikah däim atau mutah. Namun demikian, jika dirujuk pada pendapat mazhab Shāfi'i, yang juga banyak dianut Muslim Yaman Utara nampaknya aturan perkawinan beda agamanya tidak sejalan. Mazhab Shāfi'ì berpendapat bahwa menikahi Abl al-Kitäb makruh hukumnya apabila mereka berada di dār al-Islām dan lebih makruh lagi jika mereka berada di dār al-harb. Ini berarti Yaman Utara beranjak dari pendapat mazhab Shāfiì karena Hukum Keluarga Yaman Utara tidak menghindari perkawinan dengan wanita Abl al-Kitāb. Meskipun dalam fikih, makruh bukan berarti dilarang secara mutlak, tapi pada umumnya ketika dikenakan hukum makruh, maka akan dihindari.

Hukum Keluarga Yaman Utarajuga tampaknyahanya menafsirkan Alquran (Q.s. Al-Māidah [5]: 5) secara tekstual tanpa melihat mudarat yang ditimbulkan akibat perkawinan beda agama. Sebagaimana sudah ditegaskan oleh 'Umar ibn al-Khațtāb bahwa menikahi Abl alKitāb akan mendatangkan pengaruh negatif yang tidak diinginkan karena laki-laki Muslim akan lebih tertarik kepada wanita Ahl al-Kitāb ketimbang para Muslimah. Prinsip 'Umar dalam menghukumi perkawinan dengan

${ }^{20}$ Tahir Mahmood, Personal Law in Islamic Countries, h. 166. Lihat pula Barbara Freyer Stowasser dan Zeinab Abul-Magd, Tahlil Marriage in Shari'a, Legal Codes, and the Contemporarey Fatwa Literature, dalam Yvonne Yazbeck Haddad dan Barbara Freyer Stowasser, Islamic Law and the Challenges of Modernity, (Walnut Creek: Altamira Press, 2004), h. 176.
Abl al-Kitäb ini menggunakan metode sad al-dharīah, yaitu menutup bahaya yang ditimbulkan akibat suatu perbuatan yang dapat menimbulkan bahaya.

Perkawinan beda agama di Yordania diatur dalam Undang-undang Hukum Keluarga (Qānūn al-Aḥwāl al-Shakhsiyyah) 1976 yang diamandemen dengan Undang-undang No. 251977/ (Qānūn al-Ahwāl alShakbsiyyah). ${ }^{21}$ Di dalam pasal 33 Undang-undang ini disebutkan, "Perkawinan batal dalam kondisi berikut ini: (1) seorang perempuan Muslimah menikah dengan laki-laki non-Muslim, (2) Laki-laki Muslim menikahi perempuan bukan Abl al-Kitāb."

Pasal ini menegaskan bahwa perkawinan beda agama yang diperbolehkan apabila laki-laki Muslim menikah dengan $A b l$ al-Kitäb. Jika perempuannya Muslim sedangkan isterinya non-Muslim yang Abl alKitāb, maka perkawinan dapat dibatalkan. Prinsip ini menegaskan kesamaannya dengan ijma ulama tentang hukum perkawinan beda agama terhadap Abl al-Kitāb.

Yordania sebagai negarayang mayoritas penduduknya adalah Sunnī mazhab Hanafī sesungguhnya beranjak dari pendapat mazhab Hanafī yang menyatakan bahwa menikahi wanita Abl al-Kitäb adalah makruh. Bahkan, menurut 'Abd al-Raḥmān al-Jāzirī, Mazhab Hanafī mengharamkan menikahi Abl al-Kitāb yang berada di dãr al-harb. Meskipun Mazhab Hanafī hanya menghukumi makruh, Hukum Keluarga Yordani justru tidak melarang perkawinan dengan wanita $A h l$ al-Kitāb.

Tidak dilarangnya perkawinan dengan wanita $A b l$ al-Kitāb di Yordania merupakan kecenderungan kuat Hukum Keluarga Yordania yang tidak begitu serius mengambil pendapat imam-imam mazhab yang pada umumnya berpendapat makruh, yang cenderung mestinya dihindari dalam bahasa fikih. Ini artinya, hukum perkawinan beda agama di Yordan mengambil pemahaman dan penafsiran dari Alquran, surah alMā’idah [5] ayat 5 yang membolehkan laki-laki Muslim menikahi wanita $A b l$ al-Kitäb dan mengharamkan wanita Muslimah dinikahi oleh Ahl al-Kitāb/Musyrik.

Hukum Perkawinan di Yordania secara tegas akan membatalkan setiap perkawinan beda agama, yaitu laki-laki Muslim yang menikah dengan wanita bukan Abl al-Kitāb atau Wanita Muslimah menikah dengan Abl al-Kitāb. Namun demikian, Hukum Keluarga di Yordania tidak menjelaskan siapa yang dimaksud $A b l$ al-Kitāb. Karena para imam mazhab sudah sejak lama memperdebatkan siapa Abl al-Kitäb. Pada umumnya, mereka berpendapat bahwa yang dimaksud Ahlal-Kitäb

${ }^{21}$ Tahir Mahmood, Personal Law in Islamic Countries, h. 74-75. 
adalah Yahudi dan Nasrani karena mereka memiliki Taurat dan Injil, sedangkan agama lainnya tidak masuk dalam kategori Ahl al-Kitāb.

Perkawinan beda agama di Aljazair diatur dalam Undang-undang Hukum Perdata No. 11 tahun 1984 (Civil Code).22 Pasal 31 menyebutkan, "Seorang perempuan Muslimah tidak dapat menikah dengan seorang laki-laki non-Muslim.” Pasal ini menegaskan bahwa adanya larangan perempuan Muslimah dinikahkan dengan laki-laki non-Muslim. Hal ini tentu saja tidak berbeda dengan pandangan kebanyakan ulama yang bersepakat kebolehan laki-laki menikah dengan Abl al-Kitäb dan sebaliknya dilarang perempuan menikah dengan non-Muslim. Mazhab Mālikī yang dianut mayoritas masyarakat Aljazair berpendapat bahwa menikahi wanita $A h l$ al-Kitāb adalah makruh, seperti halnya pendapat mazhab fikih lainnya, seperti mazhab Hanafì dan Shāfí̄. Inilah letak perbedaan antara materi hukum perkawinan beda agama dalam Hukum Keluarga di Mālikī dengan pendapat mazhab Mālikī.

Aturan perkawinan beda agama di Aljazair hanya diatur satu pasal tentang perempuan Muslimah yang dilarang menikah dengan laki-laki non-Muslim. Ini berarti laki-laki Muslim boleh menikahi wanita $A b l$ al-Kitāb. Ketentuan ini tidak menjelaskan status perempuan yang telah menikah dengan laki-laki nonMuslim, apakah dibatalkan atau tidak.

Perkawinan beda agama di Irak diatur dalam Undang-undang Hukum Keluarga (Code of Personal Status) 1959 yang diamandemen dengan Undangundang No. 11,1980/155/1980/57/1978/21 ,1963/ 1981/125/1980/189/ dan 341983/). Pasal 17 menyebutkan, "Perkawinan seorang laki-laki Muslim dengan Ahl al-Kitäb adalah sah, tetapi perkawinan perempuan Muslimah dengan laki-laki non-Muslim tidak diperbolehkan".

Dengan ketetapan ini, maka perempuan Muslimah dilarang menikah dengan laki-laki non-Muslim, apakah Abl al-Kitäb ataupun tidak dan pada posisi sebaliknya diperbolehkan. Ketetapan ini menegaskan bahwahukum perkawinan beda agama di Irak yang penduduknya adalah mayoritas Syiah dan Sunnī (Hanafí) ${ }^{23}$ tampak tidak sepenuhnya mengikuti pendapat Hanafī yang memakruhkan perkawinan laki-laki Muslim dengan wanita Ahl al-Kitäb. Tetapi, hukum perkawinan beda agama di Irak justru mengikuti pendapat Syiah yang membolehkan laki-laki Muslim menikahi wanita $A h l$ al-Kitāb.

\footnotetext{
${ }^{22}$ Tahir Mahmood, Personal Law in Islamic Countries, h. 16-17.

${ }^{23}$ Reeva S. Simon, Philip Mattar, Richard W. Bulliet, Encyclopedia of the Modern Middle East, volume 2, h. 881.
}

Tabel Perkawinan Beda Agama

di Yaman Utara, Yordania, Aljazair, dan Irak

\begin{tabular}{|c|c|c|c|}
\hline Negara & $\begin{array}{l}\text { Undang- } \\
\text { undang }\end{array}$ & Materi & Keterangan \\
\hline $\begin{array}{l}\text { Yaman } \\
\text { Utara }\end{array}$ & $\begin{array}{l}\text { Qänün al- } \\
\text { Usrah, } 1978\end{array}$ & $\begin{array}{l}\text { Pasal 47, "Ketika } \\
\text { seorang suami } \\
\text { non-Muslim } \\
\text { masuk Islam dan } \\
\text { isterinya yang } \\
\text { bukan Ahl al- } \\
\text { Kitäb tidak masuk } \\
\text { Islam atau agama } \\
\text { Ablal-Kitäb, } \\
\text { maka perkawinan } \\
\text { tersebut dapat } \\
\text { dibatalkan. Ketika } \\
\text { seorang isteri non- } \\
\text { Muslim masuk } \\
\text { Islam sementara } \\
\text { suaminya tetap } \\
\text { non-Muslim, } \\
\text { perkawinan dapat } \\
\text { dibatalkan. Ketika } \\
\text { salah seorang } \\
\text { suami-istri keluar } \\
\text { dari Islam, maka } \\
\text { perkawinan } \\
\text { dibatalkan". }\end{array}$ & $\begin{array}{l}\text { - Negara } \\
\text { Islam (sistem } \\
\text { presidensial) } \\
\text { - Syiah } \\
\text { Zaidiyah- } \\
\text { Mazhab } \\
\text { Syāfi'i } \\
\text { - Islam adalah } \\
\text { agama negara } \\
\text { - Syariah } \\
\text { sebagai } \\
\text { sumber } \\
\text { legislasi } \\
\text { - Dijajah } \\
\text { Inggris }\end{array}$ \\
\hline $\begin{array}{l}\text { Yorda- } \\
\text { nia }\end{array}$ & $\begin{array}{l}\text { Qänün } \\
\text { al-Ahwal al- } \\
\text { Shakhsiyyah } \\
1976 \text { yang } \\
\text { diaman- } \\
\text { demen } \\
\text { (Q̄anun } \\
\text { al-Ahwal al- } \\
\text { Shakhsiy- } \\
\text { yah) } 1977\end{array}$ & $\begin{array}{l}\text { Pasal 33 } \\
\text { "Perkawinan } \\
\text { batal dalam } \\
\text { kondisi berikut } \\
\text { ini: (1) seorang } \\
\text { perempuan } \\
\text { Muslimah } \\
\text { menikah dengan } \\
\text { laki-laki non- } \\
\text { Muslim, (2) } \\
\text { Laki-laki Muslim } \\
\text { menikahi } \\
\text { perempuan bukan } \\
\text { Ablal-Kitāb. }\end{array}$ & $\begin{array}{l}\text { - Monarki } \\
\text { konstitu- } \\
\text { sional } \\
\text { - Islam sebagai } \\
\text { agama } \\
\text { Negara } \\
\text { - Mazhab } \\
\text { Hanafī } \\
\text { - Dijajah } \\
\text { Inggris }\end{array}$ \\
\hline Aljazair & $\begin{array}{l}\text { Undang- } \\
\text { undang } \\
\text { Hukum } \\
\text { Perdata No } \\
11 \text { tahun } \\
1984 \text { (Civil } \\
\text { Code) Al- } \\
\text { Jazair. }\end{array}$ & $\begin{array}{l}\text { Pasal 31, "Seorang } \\
\text { perempuan } \\
\text { muslimah tidak } \\
\text { dapat menikah } \\
\text { dengan seorang } \\
\text { laki-laki non- } \\
\text { Muslim. }\end{array}$ & $\begin{array}{l}\text { - Negara } \\
\text { Republik } \\
\text { (sistem } \\
\text { presidensial) } \\
\text { - Konstitusi: } \\
\text { Islam sebagai } \\
\text { agama } \\
\text { negara } \\
\text { - Mazhab } \\
\text { Mālikī } \\
\text { - Dijajah } \\
\text { Prancis } \\
\end{array}$ \\
\hline Irak & $\begin{array}{l}\text { Undang- } \\
\text { undang } \\
\text { Hukum } \\
\text { Keluarga } \\
\text { (Code of } \\
\text { Personal } \\
\text { Status) } \\
1959 \text { yang } \\
\text { diaman- } \\
\text { demen } \\
\text { dengan } \\
\text { Undang- } \\
\text { undang } \\
\text { 34/1983). }\end{array}$ & $\begin{array}{l}\text { Pasal 17, } \\
\text { "Perkawinan } \\
\text { seorang laki-laki } \\
\text { Muslim dengan } \\
\text { Abl al-Kitäb } \\
\text { adalah sah, tetapi } \\
\text { perkawinan } \\
\text { perempuan } \\
\text { Muslimah dengan } \\
\text { laki-laki non- } \\
\text { Muslim tidak } \\
\text { diperboleh-kan". }\end{array}$ & $\begin{array}{l}\text { Sunni } \\
\text { (Mazhab } \\
\text { Hanafí)- } \\
\text { Syiah } \\
\text { (Ja'fari) } \\
\text { - Dijajah } \\
\text { Inggris }\end{array}$ \\
\hline
\end{tabular}

Sumber: Tahir Mahmood, Personal Law in Islamic Countries, History, Text, and Comparative Analysis, New Delhi, Academy of Law and Religion, 1987 


\section{Fikih: Keterdesakan Perubahan}

Yaman Utara, Yordania, Aljazair, dan Irak adalah negara-negara Muslim yang memiliki karakteristik yang unik dalam mengatur hukum perkawinan beda agama, terutama pada status laki-laki Muslim yang menikah dengan wanita Abl al-Kitäb. Pertama, dari sudut pandang Sunni-Syiah dan imam-imam mazhab. Dilihat dari aspek ini, Yaman Utara dan Irak memiliki penganut Syiah yang relatif besar, yang berpaham Zaidiyah dan Ja fariyah. Sedangkan Aljazair dan Yordania didominasi oleh Sunni. Adapun dari aspek mazhab Fikih Sunni, Yaman Utara, Yordania, Aljazair, dan Irak didominasi oleh mazhab Mālikī, Hanafî, dan Shāfi'î.

Dari pemetaan ini, perkawinan beda agama di Yaman Utara, Yordania, Aljazair, dan Irak memiliki kecenderungan melarang perempuan Muslimah menikah dengan laki-laki non-Muslim dan kebolehan laki-laki Muslim menikah dengan wanita $\mathrm{Abl}$ al-Kitāb. Pola kecenderungan ini menunjukkan bahwa Hukum Keluarga di Yaman Utara, Yordania, Aljazair, dan Irak justru tidak sepenuhnya merujuk pada pendapat imam-imam mazhab (Mālikī, Hạafí, dan Shāfīì) yang sepakat menghukumi makruh bagi laki-laki Muslim yang menikah dengan wanita Ahl al-Kitāb. Hukum perkawinan beda agama di Yaman Utara, Yordania, Aljazair, dan Irak justru merujuk langsung kepada Alquran surah al-Māidah [5] ayat 5 yang membolehkan laki-laki Muslim menikah dengan wanita Abl al-Kitāb.

Hal ini berarti pemberlakuan hukum perkawinan beda agama di Yaman Utara, Yordania, Aljazair, dan Irak tidak begitu sepenuhnya dipengaruhi oleh mazhab fikih yang dianut mayoritas penduduknya. Justru hukum perkawinan beda agama di Yaman Utara, Yordania, Aljazair, dan Irak sedikit keluar dari mainstream pendapat ulama fikih yang memakruhkan laki-laki Muslim yang menikah dengan wanita $\mathrm{Abl}$ alKitāb.

Kedua, kolonialisme Barat yang berlangsung lama di Yaman Utara, Yordania, Aljazair, dan Irak, terutama oleh Prancis dan Inggris tampaknya tidak begitu kuat memengaruhi pemikiran hukum Islam dalam soal perkawinan beda agama. Barat yang di dalam aturan hukumnya tidak melarang perkawinan beda agama apa pun statusnya, tidak memengaruhi hukum di Yaman Utara, Yordania, Aljazair, dan Irak. Empat negara ini memilih keluar dari mainstream Barat yang sekuler dan bebas dalam membuat aturan hukum tentang perkawinan beda agama. Kebudayaan Barat yang sudah diwariskan dalam kehidupan modern masyarakat Yaman Utara, Yordania, Aljazair, dan Irak tidak memengaruhi kecenderungan masyarakat Yaman Utara, Yordania,
Aljazair, dan Irak untuk memilih hukum perkawinan beda agama yang sama seperti bunyi teks Alquran. Hal ini dapat dimengerti karena persoalan hubungan antaragama dalam perkawinan merupakan isu yang sensitif dan strategis dalam masyarakat Islam. Hukum perkawinan beda agama di Yaman Utara, Yordania, Aljazair, dan Irak tidak berani beranjak pada teks Alquran untuk membebaskan segala jenis perkawinan beda agama.

Ketiga, konteks sosial-politik dalam gerakan Islam yang terjadi di Yaman Utara, Yordania, Aljazair, dan Irak menunjukkan kuatnya Islamisme, seperti Ikhwanul Muslimin di Yordania, Front Islamic Salvation di Aljazair dan kuatnya pengaruh gerakan Syiah di Irak dan Yaman Utara. Pola gerakan ini telah memperkuat konservatisme agama dalam urusan perkawinan beda agama. Tidak mengherankan jika empat negara ini mengambil jalan kembali ke teks Alquran untuk mengatur hukum perkawinan beda agama.

Jika dilihat dari Konstitusinya pun, ada kecenderungan Islam sebagai agama negara, yang memberikan bukti bahwa warna Islam di Yaman Utara, Yordania, Aljazair, dan Irak memiliki kecenderungan yang formalistik. Paradigma ini melahirkan hukumhukum yang tekstual, lebih-lebih dalam hal hubungan antaragama seperti perkawinan beda agama.

Jalan kembali ke teks Alquran dalam mengatur hukum perkawinan beda agama di Yaman Utara, Yordania, Aljazair, dan Irak sebenarnya terjadi juga di negara-negara Muslim lainnya, meskipun warna formalisme Islam tidak begitu kuat, seperti Indonesia. Namun demikian, letak perdebatannya adalah apakah Yahudi dan Nasrani masih masuk kategori Abl al-Kitäb yang sama seperti pada awalnya atau dengan kata lain apakah Yahudi dan Nasrani zaman sekarang masih asli. Jika Yahudi dan Nasrani dipandang tidak asli lagi karena sudah banyak yang diubah ajarannya, maka mereka tidak masuk dalam rumusan teks Alquran sebagai Ahl al-Kitäb. Implikasinya adalah wanita Yahudi dan Nasrani zaman sekarang tidak boleh lagi dinikahi oleh laki-laki Muslim karena teks Alquran menunjuk pada Yahudi dan Nasrani yang masih asli.

Perdebatan yang kedua adalah tentang alasan sosiologis perkawinan beda agama yang cenderung membawa mudarat, terutama dalam pemeliharaan dan pendidikan anak. Jika yang merawat dan yang mendidik anak adalah istri Abl al-Kitäb, maka akan menyebabkan anak cenderung ikut agama ibu, bukan agama bapak. Inilah mudaratnya perkawinan beda agama. Karena itulah, perkawinan beda agama cenderung dihindari untuk menghindari mudarat, sebagaimana kaidah fikih, "Kemudaratan itu dihilangkan" atau kaidah lain, 
"menghilangkan mafsadat lebih didahulukan ketimbang menarik maslahat".

Perdebatan yang ketiga adalah akibat perkawinan beda agama akan memberi peluang pada persoalan baru dalam hukum keluarga Islam, yakni tentang wali, waris, wasiat, hadānah, dan saksi perkawinan beda agama. Karena sangat dimungkinkan pasangan yang melangsungkan perkawinan beda agama akan membawa dampak terhadap substansi hukum keluarga.

\section{Penutup}

Hukum perkawinan beda agama yang diberlakukan di negara-negara Muslim, seperti Yaman Utara, Yordania, Aljazair, dan Irak sesungguhnya menunjukkan arus perdebatan yang serius dari keterikatan dengan tekstual Alquran (kebolehan laki-laki Muslim menikah dengan wanita Abl al-Kitäb) dengan mengambil jalan istinbät lain (larangan laki-laki Muslim menikah dengan wanita Abl al-Kitāb). Negara-negara ini berani tidak merujuk pada pendapat imam-imam mazhab (Mālikī, Hanafī, dan Shāfî̀) yang sepakat menghukumi makruh bagi laki-laki Muslim yang menikah dengan wanita $\mathrm{Abl}$ alKitāb.

Argumen sadd al-dharïah atau al-maslahah yang biasanya digunakan untuk melarang laki-laki Muslim menikah dengan wanita Ahl al-Kitāb tidak menjadi pertimbangan utama, sehingga hukum perkawinan beda agama dibiarkan seperti bunyi teks Alquran. Kecenderungan ini bukan berarti representasi dari liberalisme Islam, yang cenderung membolehkan lakilaki Muslim menikah dengan wanita Abl al-Kitāb. Tetapi juga, kecenderungan ini tidak memenuhi kepentingan konservatisme dan radikalisme Islam. Dengan demikian, hukum perkawinan beda agama di Yaman Utara, Yordania, Aljazair, dan Irak cenderung bertahan dengan tekstualitas Alquran tanpa pernah dipengaruhi oleh radikalisme dan liberalisme Islam.

Meskipun tidak dominan, pemberlakuan hukum perkawinan beda agama di Yaman Utara, Yordania, Aljazair, dan Irak tetap menggunakan pertimbangan yang kompleks, seperti konteks sosial-politik gerakan Islam, kolonialisme, pendapat imam-imam mazhab, dan teks terutama Alquran. Ini berarti bahwa perdebatan pemberlakuan hukum perkawinan beda agama di suatu negara akan sangat beriringan dengan kompleksitas yang dialami oleh negara dalam mengelola perbedaan ideologi, sosial, dan politik. []

\section{Pustaka Acuan}

'Azzām, 'Abd al-'Azīz Muḥammad dan Ḥawwās, 'Abd al-Wahhāb Sayyed Hawwās, al-Usrah wa Aḥkàmuhā fi al-Tashrī' al-Islämī, terjemahan dengan judul, Fiqh Munakahat, Jakarta: Sinar Grafika Offset, 2009.

Esposito, John L. dan John O. Voll, Demokrasi di Negara-negara Muslim, Problem dan Prospek, Bandung: Mizan, 1999.

----------, Ensiklopedi Dunia Islam Modern, jilid VI, cet. II, Bandung: Mizan, 2002.

Haddad, Yvonne Yazbeck dan Stowasser, Barbara Freyer, Islamic Law and the Challenges of Modernity, Walnut Creek: Altamira Press, 2004.

Hasbi, Rusli, Rekonstruksi Hukum Islam: Kajian Kritis Sahabat Terhadap Ketetapan Rasulullah Saw, Jakarta: Al-Irfan Publishing, 2007.

Ibn Qudāmah, al-Sharḥ al-Kabìr 'alā Matn al-Mughnī, Jilid VII, Suriah: Dār al-Bayān, t.th.

Jașsāạ, al-, Abū Bakr, Aḥkām al-Qur'ān, Jilid I, tp. t.t.

Jāzirī, al-, 'Abd al-Raḥmān, Kitāb al-Fiqh 'alā Madzahib al-Arba'ah, jilid 4, Beirut: Dar al-Fikr al-Ilmiyah, t.th.

Mahmood, Tahir, Personal Law in Islamic Countries, History, Text, and Comparative Analysis, New Delhi, Academy of Law and Religion, 1987.

Mughniyah, Muhammad Jawad, Fikih Lima Mazhab, cet. IV, Jakarta: PT. Lentera Basritama, 1999.

Mudzhar, M. Atho dan Nasution, Khairuddin (ed.), Hukum Keluarga di Dunia Islam Modern: Studi Perbandingan dan Keberanjakan UU Modern dari Kitab-kitab Fikih, Jakarta: Ciputat Press, 2003.

Simon, Reeva S., Philip Mattar, Richard W. Bulliet, Encyclopedia of the Modern Middle East, volume 2, New York: Macmillan Reference USA, 1996.

Vikor, Knut S., Between God and the Sultan: A History f Islamic Law, New York: Oxford University Press, 2005.

Zuhaylī, al-, Wahbah, al-Figh al-Islāmī wa Adillatuh, jilid IX, Bayrūt: Dār al-Fikr, 1997. 